\title{
Aktivitas Enzimatik Isolat Trametes spp. dari Kebun Raya Baturraden dalam Pewarna Batik dengan Variasi Konsentrasi Indigosol Blue Glukosa
}

\author{
Mutia Syarifah Adrir ${ }^{1 *}$, Ratna Stia Dewi ${ }^{1}$, Ajeng Arum Sari ${ }^{2}$ \\ ${ }^{1}$ Fakultas Biologi, Universitas Jenderal Soedirman \\ ${ }^{2}$ Pusat Penelitian Kimia, Lembaga Ilmu Pengetahuan Indonesia (LIPI) \\ Email: mutiasyarifah19@gmail.com
}

Rekam Jejak Artikel:

Diterima : 23/09/2019

Disetujui : 25/07/2020

\begin{abstract}
Indigosol Blue is one of Antraquinone synthetic dyes which is used as a blue dye in the textile industry and is recalcitrant and non-biodegradable, so it is not easily damaged by chemical or photolytic treatments. Trametes sp. isolate is believed to have the ability to transform dye components through an enzymatic degradation mechanism. This ability is due to the fungus able to produce ligninolytic extracellular enzymes that can degrade xenobiotic components in indigosol dye waste into non-toxic forms in the environment. The study aims to determine the ability of three test isolates to produce enzymes in Indigosol Blue dyes at different glucose concentrations and to determine isolate with optimum glucose concentrations that have the best enzyme activity in Indigosol Blue dyes. Measurement of enzymatic activity was carried out by the spectrophotometric method. The results showed that the test isolates could produce enzymes in Indigosol Blue dyes at different glucose concentrations. Enzyme activity in each treatment is different and shows significant results. Further test data showed that Trametes sp. strain A has the best enzyme activity in the Indigosol Blue dye with a glucose concentration of $0.5 \%$. This research also showed that glucose concentrations above $0.5 \%$ could inhibit lacase activity, so that lacase activity in dyes is low.

Key Words: ligninolytic enzymes, fungi, glucose, Indigosol Blue, Trametes sp.
\end{abstract}

\begin{abstract}
Abstrak
Indigosol Blue merupakan salah satu zat warna sintetik Antraquinon yang digunakan sebagai pewarna biru pada industri pencelupan tekstil dan bersifat rekalsitran dan non-biodegradable, sehingga tidak mudah rusak oleh perlakuan kimia maupun fotolitik. Isolat Trametes sp. diyakini memiliki kemampuan mentransformasi komponen pewarna melalui mekanisme degradasi enzimatik. Trametes sp. mampu menghasilkan enzim ekstraseluler ligninolitik yang dapat mendegradasi komponen xenobiotik dalam limbah pewarna indigosol menjadi bentuk yang tidak toksik di lingkungan. Penelitian bertujuan untuk mengetahui kemampuan tiga isolat uji dalam menghasilkan enzim dalam pewarna Indigosol Blue pada konsentrasi glukosa berbeda serta mengetahui isolat dengan konsentrasi glukosa optimum yang memiliki aktivitas enzim terbaik dalam pewarna Indigosol Blue. Pengukuran aktivitas enzimatik dilakukan dengan metode spektrofotometri. Hasil penelitian menunjukkan bahwa isolat-isolat uji dapat menghasilkan enzim dalam pewarna Indigosol Blue pada konsentrasi glukosa berbeda. Aktivitas enzim pada masing-masing perlakuan berbeda-beda dan menunjukkan hasil yang signifikan. Data uji lanjut memperlihatkan bahwa isolat Trametes sp. strain A memiliki aktivitas enzim terbaik dalam pewarna Indigosol Blue dengan konsentrasi glukosa $0,5 \%$. Penelitian juga menunjukkan bahwa konsentrasi glukosa di atas $0.5 \%$ dapat menghambat aktivitas lakase, sehingga aktivitas lakase dalam zat pewarna rendah.
\end{abstract}

Kata kunci: enzim ligninolitik, fungi, glukosa, Indigosol Blue, Trametes sp.

\section{PENDAHULUAN}

Indonesia merupakan negara kepulauan yang kaya akan sumber daya dan aneka ragam warisan budaya, salah satunya adalah batik yang merupakan karya seni bernilai tinggi (Mahfudloh \& Lestari, 2017). Selain sebagai komoditi ekspor yang memberikan dampak positif pada devisa negara, industri batik juga memberikan dampak negatif berupa limbah cair batik yang menyebabkan penurunan kualitas lingkungan dan kesehatan
(Sumarko et al., 2013). Limbah zat warna yang dihasilkan dari industri tekstil setelah proses pewarnaan umumnya merupakan senyawa organik berbahan sintetik yang sukar larut dan nonbiodegradable, sehingga dapat menyebabkan pencemaran lingkungan (Suprihatatin, 2014).

Zat warna yang digunakan dalam proses pembatikan contohnya yaitu Indigosol (Kartikasari et al., 2012). Indigosol Blue merupakan salah satu zat warna sintetik Antraquinon yang digunakan sebagai pewarna biru pada industri pencelupan 
tekstil dan bersifat tidak mudah rusak oleh perlakuan kimia maupun fotolitik. Bila air limbah tekstil yang mengandung zat warna sintetik terbuang ke lingkungan, maka dapat bertahan lama dan mengalami akumulasi sampai pada tingkat konsentrasi tertentu sehingga dapat menimbulkan dampak negatif terhadap daya dukung lingkungan (Herfiani et al., 2017).

Penghilangan warna dan senyawa organik yang ada dalam limbah zat warna industri batik telah banyak dilakukan, yaitu dengan metode fisika dan kimia melalui filtrasi membran, adsorbsi, pertukaran ion, ozonasi, flokulasi-koagulasi, dan oksidasi (Ngieng et al., 2013). Metode ini dapat memperbaiki kualitas air dalam waktu singkat, namun metode ini memerlukan biaya yang mahal, aplikasinya terbatas area, dan dapat menimbulkan polusi sekunder karena menggunakan bahan-bahan kimia dalam prosesnya (Salleh et al., 2011; Turhan et al., 2012). Oleh karena itu, metode biologi menggunakan jamur menjadi alternatif, karena kemampuannya dalam proses adsorbsi dan degradasi berbagai polutan kimia kompleks (Wang et al., 2017).

Jamur jenis Basidiomycota diketahui memiliki kemampuan dalam mendegradasi atau menghilangkan zat pewarna (Munir et al., 2018). Terutama kelompok white rot fungi adalah organisme yang paling efisien dalam dekolorisasi dan degradasi pewarna (Yesilada et al., 2018). Spesies white rot fungi dari genus Trametes telah diteliti mampu mendekolorisasi pewarna tekstil seperti Orange II (Yesilada et al., 2018), Remazol Brilliant Blue $R$ (RBBR) (Mechichi et al., 2006), dan Malachite Green (Maalej-Kammoun et al., 2009). Sari \& Dewi (2019) melaporkan tiga isolat yang teridentifikasi sebagai Trametes spp. terseleksi untuk dekolorisasi limbah Indigosol Blue, namun belum dilakukan uji aktivitas enzim ketiga isolat tersebut, sehingga perlu dilakukan penelitian lebih lanjut. Proses dekolorisasi pewarna tekstil oleh Trametes sp. diketahui melibatkan beberapa enzim ligninolitik ekstraseluler yang dihasilkan selama metabolisme seperti lakase (Zapata-Castillo et al., 2015). Lakase mampu mendekolorisasi berbagai jenis pewarna sintetik seperti Acid Blue, Reactive Black 5, Basic Red 9, Remazol Brilliant Blue R, Indigo, dan sebagainya (Castillo et al., 2012; Abadulla et al., 2000). Enzim ini mampu mengubah komponen xenobiotik dalam limbah pewarna menjadi bentuk yang tidak toksik di lingkungan sehingga dapat digunakan sebagai alternatif bioremediasi pewarna tekstil (Yesilada et al., 2018).

Aktivitas enzim lakase dalam zat warna dipengaruhi oleh beberapa faktor lingkungan seperti sumber karbon, nitrogen, fosfor, $\mathrm{pH}$, suhu, konsentrasi zat warna, konsentrasi inokulum, dan aerasi atau statis (Martina et al., 2015). Sintesis dan sekresi enzim lakase terutama dipengaruhi oleh ketersediaan sumber karbon (Senthilkumar et al.,
2014). Sumber karbon utama yang digunakan oleh sebagian besar jamur adalah glukosa (Kaushik \& Malik, 2009). Pengujian dengan variasi konsentrasi glukosa sebagai sumber karbon menghasilkan aktivitas enzim yang berbeda. Aktivitas enzim optimal dengan konsentrasi glukosa $0,5 \%$, namun semakin menurun dengan konsentrasi glukosa yang semakin tinggi (Senthilkumar et al., 2014). Oleh karena itu, diperlukan penelitian variasi konsentrasi glukosa untuk mengetahui aktivitas enzim dalam pewarna Indigosol Blue yang optimum.

Tujuan dari penelitian ini adalah untuk mengetahui kemampuan tiga isolat uji dalam menghasilkan enzim dalam pewarna Indigosol Blue pada konsentrasi glukosa berbeda, serta mengetahui isolat dengan konsentrasi glukosa optimum yang memiliki aktivitas enzim terbaik dalam pewarna Indigosol Blue. Hasil dari penelitian ini diharapkan dapat memberikan informasi ilmiah mengenai kemampuan enzimatis tiga isolat uji dan isolat dengan konsentrasi glukosa optimum yang memiliki aktivitas enzim terbaik untuk mendegradasi Indigosol Blue.

\section{MATERI DAN METODE}

Penelitian ini dilaksanakan di Laboratorium Kimia Pusat Penelitian Kimia LIPI, Serpong. Sampel berupa koleksi isolat Basidiomycota dari kawasan Kebun Raya Baturraden. Bahan yang digunakan dalam penelitian ini medium Potato Dextrose Agar (PDA), medium Malt Extract (ME), crude enzyme Mangan Peroksidase (MnP), Lignin Peroksidase (LiP), dan Lakase, larutan 2,6dimethylphenol (2,6-DMP), larutan buffer malonat $\mathrm{pH} 4,5$, mangan sulfat (MnSO4), $\mathrm{H} 2 \mathrm{O} 230 \%$, larutan buffer sodium tartrat $\mathrm{pH} 2,9$, buffer LiP, syringaldazine, larutan buffer $\mathrm{NaH} 2 \mathrm{PO} 4$, larutan buffer sodium asetat $\mathrm{pH} 5,3$, limbah pewarna Indigosol Blue.

Metode yang digunakan dalam penelitian adalah eksperimental dengan Rancangan Acak Lengkap (RAL). Variabel bebasnya adalah tiga jenis isolat dan konsentrasi glukosa $(0,0,5,1$, dan $2 \%)$, sedangkan variabel terikatnya adalah kemampuan isolat dalam menghasilkan enzim. Parameter utama yang diamati adalah aktivitas enzim lakase. Parameter pendukung yang diamati adalah nilai bobot kering miselium.

\section{Pembuatan Medium Pertumbuhan dan Sterilisasi Alat}

Medium pertumbuhan yang digunakan adalah medium PDA dan medium malt extract. Alat-alat gelas dan medium pertumbuhan (PDA dan malt extract) disterilisasi menggunakan autoklaf dengan suhu $121^{\circ} \mathrm{C}$ dan pada tekanan 2 atm selama 15 menit.

\section{Peremajaan Isolat Isolat Trametes spp.}

Isolat Trametes spp. koleksi Pusat Penelitian Kimia LIPI yang diisolasi dari Kebun Raya 
Baturraden diremajakan di medium PDA untuk diperbanyak dan ditumbuhkan selama 5 hari.

Kultivasi Isolat Trametes spp. pada Medium Malt Extract (Sari et al., 2012)

Glukosa ditimbang untuk pembuatan medium malt extract dengan konsentrasi $0 \%, 0,5 \%, 1 \%$, dan $2 \%$ (w/w). Medium malt extract disiapkan sebanyak $100 \mathrm{~mL}$ pada labu Erlenmeyer $250 \mathrm{~mL}$ dengan penambahan glukosa sesuai konsentrasi. Sebanyak lima plug koloni miselium isolat Trametes spp. dengan diameter sebesar $5 \mathrm{~mm}$ dari medium PDA diinokulasikan ke dalam medium malt extract. Medium yang telah diinokulasikan kemudian ditutup menggunakan kapas dan diinkubasi pada shaker dengan kecepatan $150 \mathrm{rpm}$ selama 7 hari pada suhu ruang ${ }^{\circ} \mathrm{C}$.

Uji Aktivitas Enzimatik (Senthilkumar et al., 2014; Zavarzina \& Zavarzin, 2006; Zahra, 2017)

Sebanyak $10 \mathrm{~mL}$ larutan pewarna Indigosol Blue ditambahkan ke dalam kultur Trametes spp. Kultur ditutup menggunakan kapas dan diinkubasi dalam shaker dengan kecepatan $150 \mathrm{rpm}$ selama 24 jam pada suhu $25{ }^{\circ} \mathrm{C}$. Sampel diambil sebanyak 1 $\mathrm{mL}$ dan diukur aktivitas enzimnya menggunakan spektrofotometer.

Aktivitas lakase diukur dengan mengamati oksidasi syringaldazine menjadi quinone dalam larutan buffer $\mathrm{NaH}_{2} \mathrm{PO}_{4}$ 0,1 M. Uji ini menggunakan larutan syringaldazine dan buffer sodium asetat Larutan dimasukkan ke dalam kuvet dan dilakukan pembacaan absorbansi pada panjang gelombang 525 $\mathrm{nm}$ menggunakan UV-vis spektrofotometer dengan suhu $20{ }^{\circ} \mathrm{C}$. Akuades digunakan sebagai larutan blanko.
Pengukuran Berat Kering Miselium isolat Trametes spp. (Sulistyaningtyas \& Suprihadi, 2017) Pengukuran berat kering dilakukan setelah melakukan pengukuran berat basah miselium. Kertas saring yang digunakan untuk menyaring miselium kemudian dikeringkan menggunakan oven dengan suhu $60{ }^{\circ} \mathrm{C}$ selama 2 hari. Kertas saring ditimbang. Berat kering miselium ditentukan dari hasil pengurangan antara kertas saring yang digunakan untuk menyaring dengan berat kering kertas saring sebelum digunakan.

\section{HASIL DAN PEMBAHASAN}

Isolat Trametes spp. yang diuji merupakan hasil seleksi tiga puluh sampel yang diisolasi dari beberapa titik di kebun raya Baturraden, diantaranya adalah Trametes sp. strain A, Trametes sp. strain B, dan Trametes sp. strain C. Ketiga isolat merupakan isolat terseleksi yang mempunyai kemampuan dekolorisasi tertinggi dalam pewarna Indigosol Blue pada penelitian sebelumnya oleh Sari \& Dewi (2019). Tiga isolat tersebut dilakukan pengujian aktivitas enzim untuk mengetahui kemampuan enzimatik yang dimiliki dengan perlakuan konsentrasi glukosa. Nilai aktivitas enzim lakase Trametes sp. strain A dengan konsentrasi glukosa 0; 0,5 ; 1 ; dan $2 \%$ berturut-turut adalah 41,$69 ; 203,23$; 31,57; dan 17,74 U/L, Trametes sp. strain B dengan konsentrasi glukosa $0 ; 0,5 ; 1$; dan $2 \%$ berturut-turut adalah 28,42; 28,39; 24,48; dan 36,49 U/L, Trametes sp. strain C dengan konsentrasi glukosa 0 ; 0,5 ; 1 ; dan $2 \%$ berturut-turut adalah 33,$34 ; 32,55$; 32,57; dan 32,60 U/L. Data aktivitas enzim lakase dicantumkan dalam Gambar 1.

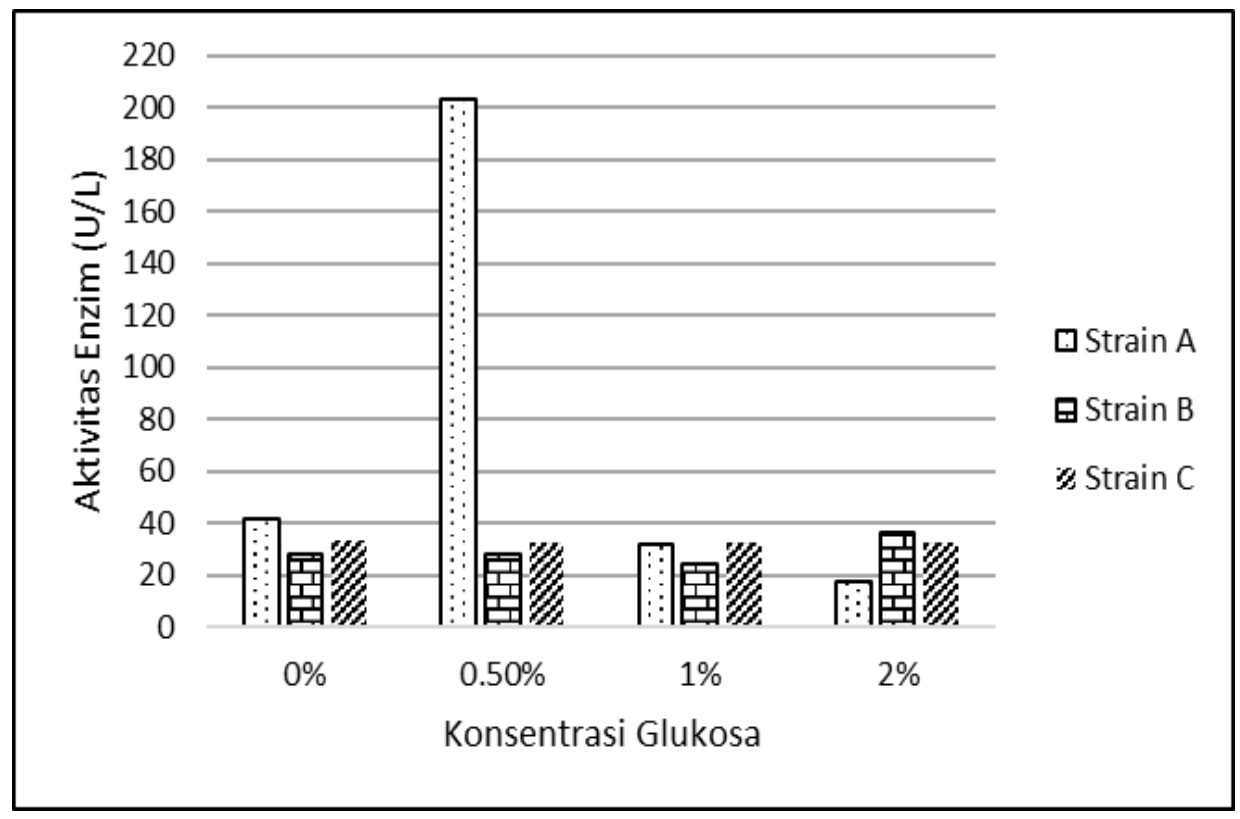

Gambar 1. Data aktivitas enzim lakase isolat Trametes spp. (strain A, strain B, strain C) yang diisolasi dari Kebun Raya Baturraden dalam pewarna batik Indigosol Blue dengan variasi konsentrasi glukosa 
Konsentrasi glukosa yang bervariasi dalam pewarna Indigosol Blue mengakibatkan aktivitas enzim lakase tiap perlakuan berbeda-beda. Hal ini sesuai degan penelitian Babic et al. (2012) yang melaporkan bahwa perlakuan dengan konsentrasi glukosa bervariasi menghasilkan aktivitas enzim lakase yang berbeda-beda. Konsentrasi glukosa
$2,824 \mathrm{~g} / \mathrm{L}$ dan 8,176 g/L menunjukkan aktivitas enzim lakase berbeda, yaitu 32,02 U/L dan 20,67 U/L. Schneider et al. (2018) juga melaporkan bahwa dengan glukosa $5 \mathrm{~g} / \mathrm{L}, 10 \mathrm{~g} / \mathrm{L}, 20 \mathrm{~g} / \mathrm{L}$, dan $30 \mathrm{~g} / \mathrm{L}$ menunjukkan aktivitas lakase berbeda-beda, yaitu secara berurutan 3219 U/L, 3420 U/L, 1783 U/L, dan 2163 U/L.

Tabel 1. Uji Beda Nyata Jujur (BNJ) pengaruh antar perlakuan konsentrasi glukosa pada kultur Trametes spp. terhadap aktivitas enzim lakase dalam pewarna Indigosol Blue

\begin{tabular}{clc}
\hline No. & \multicolumn{1}{c}{ Perlakuan } & Rata-rata (U/L) \\
\hline 1. & Trametes sp. strain A dengan konsentrasi glukosa 0\% (A1) & $41,69 \mathrm{~b}$ \\
2. & Trametes sp. strain A dengan konsentrasi glukosa 0.5\% (A2) & $203,23 \mathrm{a}$ \\
3. & Trametes sp. strain A dengan konsentrasi glukosa 1\% (A3) & $31,57 \mathrm{~d}$ \\
4. & Trametes sp. strain A dengan konsentrasi glukosa 2\% (A4) & $17,74 \mathrm{~g}$ \\
5. & Trametes sp. strain B dengan konsentrasi glukosa 0\% (B1) & $28,42 \mathrm{e}$ \\
6. & Trametes sp. strain B dengan konsentrasi glukosa 0.5\% (B2) & $28,39 \mathrm{e}$ \\
7. & Trametes sp. strain B dengan konsentrasi glukosa 1\% (B3) & $24,48 \mathrm{f}$ \\
8. & Trametes sp. strain B dengan konsentrasi glukosa 2\% (B4) & $36,49 \mathrm{c}$ \\
9. & Trametes sp. strain C dengan konsentrasi glukosa 0\% (C1) & $33,34 \mathrm{~d}$ \\
10. & Trametes sp. strain C dengan konsentrasi glukosa 0.5\% (C2) & $32,55 \mathrm{~d}$ \\
11. & Trametes sp. strain C dengan konsentrasi glukosa 1\% (C3) & $32,57 \mathrm{~d}$ \\
12. & Trametes sp. strain C dengan konsentrasi glukosa 2\% (C4) & $32,60 \mathrm{~d}$ \\
\hline
\end{tabular}

Keterangan: angka yang diikuti huruf yang sama tidak berbeda nyata pada BNJ 5\%

Berdasarkan hasil uji BNJ, aktivitas enzim lakase pada perlakuan A2 menunjukkan pengaruh yang nyata terhadap perlakuan lainnya dan memiliki nilai tertinggi. Perlakuan konsentrasi glukosa $0,5 \%$ pada isolat Trametes sp. strain A memiliki nilai ratarata tertinggi. Hasil tersebut menunjukkan bahwa isolat Trametes sp. strain A memiliki aktivitas enzim lakase optimum dalam pewarna Indigosol Blue dengan konsentrasi glukosa 0,5\%.

Berdasarkan data uji lanjut, aktivitas enzim optimum dalam pewarna Indigosol Blue adalah dengan penambahan konsentrasi glukosa $0,5 \%$. Ottoni et al. (2016) melaporkan konsentrasi glukosa optimum yang baik bagi pertumbuhan miselium dan aktivitas lakase $T$. versicolor adalah $0,5 \%$. Aktivitas enzim lakase $T$. versicolor oleh Ottoni et al. (2016) adalah sebesar 80,2 U/L, sementara dalam penelitian ini adalah sebesar 203,23 U/L. Data tersebut menunjukkan aktivitas enzim isolat Trametes yang lebih tinggi.

Berdasarkan data, aktivitas lakase menurun ketika penambahan glukosa di atas $0,5 \%$, yaitu konsentrasi glukosa $1 \%$ dan $2 \%$. Hal ini menunjukkan bahwa peningkatan konsentrasi glukosa menyebabkan aktivitas lakase menurun. Penambahan glukosa pada konsentrasi tertentu menurut Li et al. (2011) dapat mengakibatkan produksi lakase terhambat. Konsentrasi glukosa di atas $0,5 \%$ dapat menghambat ekspresi lakase, sehingga aktivitas lakase dalam zat pewarna rendah.

Konsentrasi glukosa yang baik untuk degradasi enzimatik zat pewarna adalah $0,5 \%$, di atas konsentrasi tersebut akan menyebabkan produksi lakase menurun. Ado et al. (2018) juga melaporkan bahwa produksi lakase menurun dengan meningkatnya konsentrasi glukosa, sementara itu aktivitas lakase maksimum pada saat kondisi glukosa terbatas. Menurut Kapdan et al. (2000), glukosa berperan sebagai sumber karbon utama pada fase pertumbuhan awal jamur (fase lag) untuk pertumbuhan miselium, kemudian pada fase selanjutnya menghasilkan metabolit sekunder dan enzim-enzim ekstraseluler untuk melakukan biodegradasi zat-zat pewarna dalam kondisi sumber karbon rendah. Oleh karena itu, penambahan konsentrasi glukosa yang semakin tinggi mendorong fase pertumbuhan awal jamur berkepanjangan.

Supernatan dari masing-masing perlakuan ditunjukkan pada Gambar 4.2. Gambar 4.2 menunjukkan supernatan yang diperoleh dari perlakuan masing-masing konsentrasi glukosa. Berdasarkan data, pada perlakuan A2 terjadi perubahan warna menjadi paling jernih, serta mengalami aktivitas enzim terbaik. 


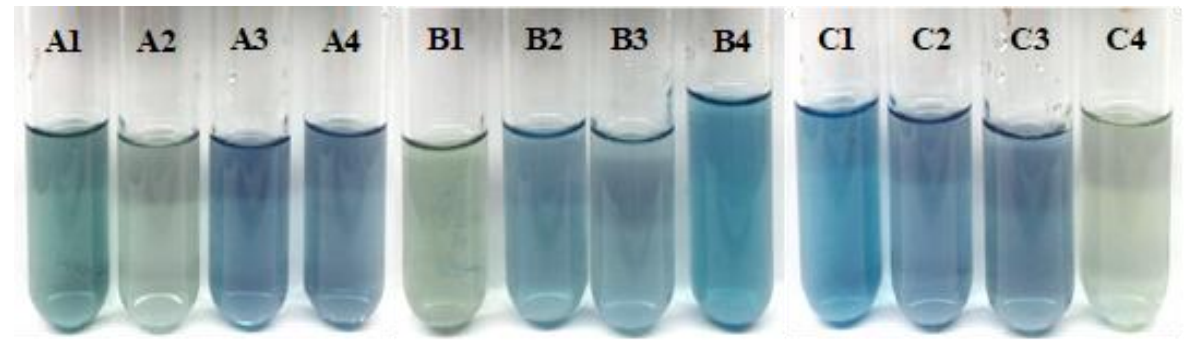

Gambar 2. Supernatan perlakuan aktivitas enzimatik isolat Trametes sp. strain A, strain B, dan strain C dengan konsentrasi glukosa berbeda

Selain aktivitas lakase, parameter pendukung berupa berat kering miselium diukur untuk mengetahui adanya hubungan antara berat miselium dengan aktivitas lakase. Berat kering miselium setelah perlakuan ditimbang dan diperoleh hasil dalam Gambar 4.3. Berdasarkan data, miselium dengan berat paling tinggi adalah perlakuan A1, yaitu isolat Trametes sp. strain A dengan konsentrasi glukosa 0\%. Hal ini menunjukkan bahwa berat miselium tidak mempengaruhi aktivitas enzim. Aktivitas enzim yang ditandai dengan penurunan warna tidak dipengaruhi oleh pertumbuhan miselium. Pertumbuhan miselium tidak mempengaruhi perubahan warna larutan. Sesuai penelitian Al-Jawhari (2015) yang menyatakan bahwa pertumbuhan miselium tidak selalu sesuai dengan penurunan warna yg melibatkan aktvitas enzim.

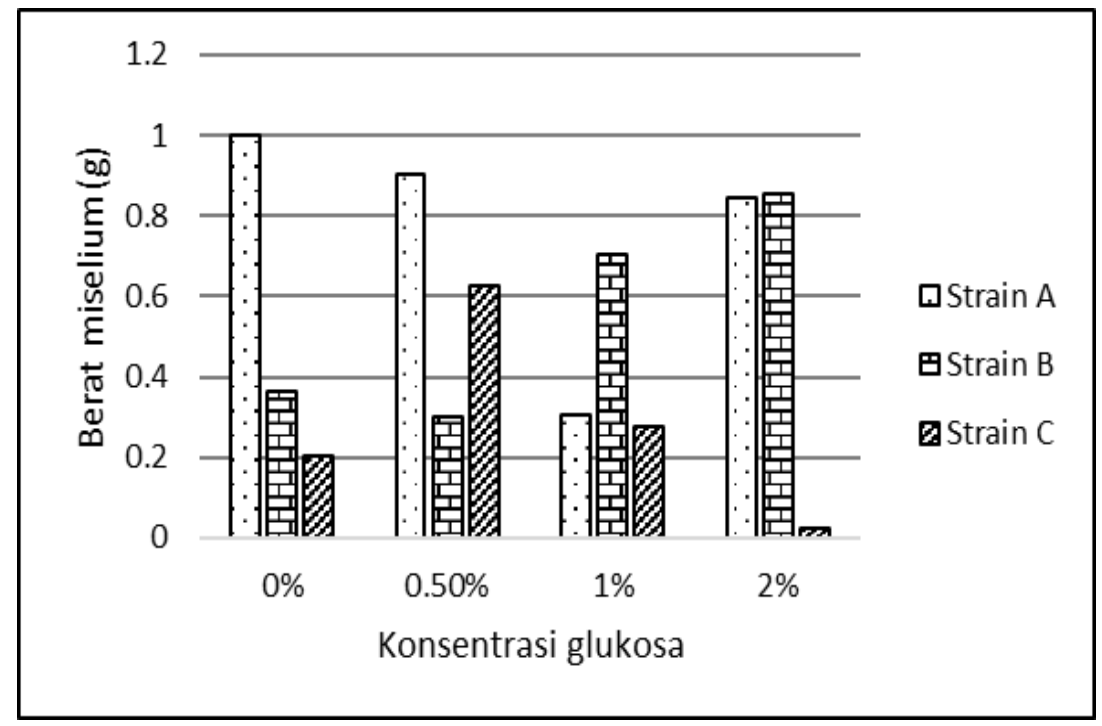

Gambar 3. Data berat kering biomassa Trametes spp. dalam pewarna Indigosol Blue

Lakase merupakan enzim oksidoreduktase yang mengkatalisis reaksi oksidasi berbagai senyawa aromatik (terutama senyawa fenolik) dengan menggunakan oksigen sebagai akseptor elektron dengan hasil akhir berupa air $\left(\mathrm{H}_{2} \mathrm{O}\right)$ (Mishra et al., 2019). Lakase mengkatalisis reaksi oksidasi substrat empat elektron, menghasilkan pembelahan reduktif ikatan dioksigen. Atom $\mathrm{Cu}$ pada sisi aktif lakase memainkan peran kunci dalam mereduksi oksigen menjadi $\mathrm{H}_{2} \mathrm{O}$. Atom $\mathrm{Cu}$ penyusun lakase yaitu satu atom tembaga tipe 1 $\left(\mathrm{Cu}_{1}\right)$, satu tembaga tipe $2\left(\mathrm{Cu}_{2}\right)$, dan dua tipe tembaga $3\left(\mathrm{Cu}_{3}\right)$ (Gambar 4.3). $\mathrm{Cu}_{1}$ berperan sebagai akseptor elektron utama dalam proses oksidasi yang dikatalisis lakase. Elektron selanjutnya ditransfer melalui tripeptida His-CysHis ke Tri-nuclear cluster (TNC) yang mencakup atom $\mathrm{Cu}_{2}$ dan $\mathrm{Cu}_{3}$. Kemudian elektron mereduksi oksigen menjadi $\mathrm{H}_{2} \mathrm{O}$ (Su et al., 2018).

Lakase banyak dimanfaatkan dalam proses degradasi lignin. Lakase mempunyai spesifitas substrat yang rendah, sehingga mampu mengkatalisis reaksi oksidasi berbagai substrat kompleks, seperti dekolorisasi pewarna tekstil (Yesilada et al., 2018). Tiga isolat Trametes spp. yang diuji diketahui mampu menghasilkan enzim lakase dan memperlihatkan aktivitas enzim yang berbeda-beda dalam pewarna Indigosol Blue. Indigosol Blue $\left(\mathrm{C}_{28} \mathrm{H}_{14} \mathrm{~N}_{2} \mathrm{O}_{4}\right)$ merupakan salah satu zat warna sintetik Antraquinon, dan memiliki ikatan molekul -NH dan $\mathrm{C}=\mathrm{C}$ (Gambar 4.4). Zat warna sintetik ini tidak mudah rusak oleh perlakuan kimia maupun fotolitik (Herfiani et al., 2017). 


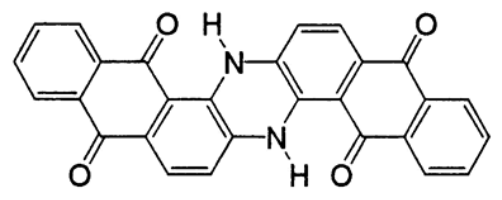

Gambar 4. Struktur molekul Indigosol Blue (Worlddyevariety.com)

Lakase dalam larutan Indigo berperan untuk melakukan pemutusan ikatan senyawa kompleks di dalamnya. Proses pemutusan ikatan ini mengakibatkan struktur kompleks Indigo pecah dan menghasilkan senyawa yang lebih sederhana seperti ditunjukkan pada bagan berikut (Gambar 4.5). Lakase mengoksidasi indigo menjadi senyawa intermediet isatin menggunakan senyawa $\mathrm{O}_{2}$. Setelah isatin terbentuk, degradasi lebih lanjut berlangsung secara hidrolitik tanpa mediasi lakase. Asam isatin intermediet yang terbentuk tidak stabil dan akan terurai secara spontan melalui dekarboksilasi yang menghasilkan asam antranilat sebagai produk degradasi akhir (Campos et al., 2001).

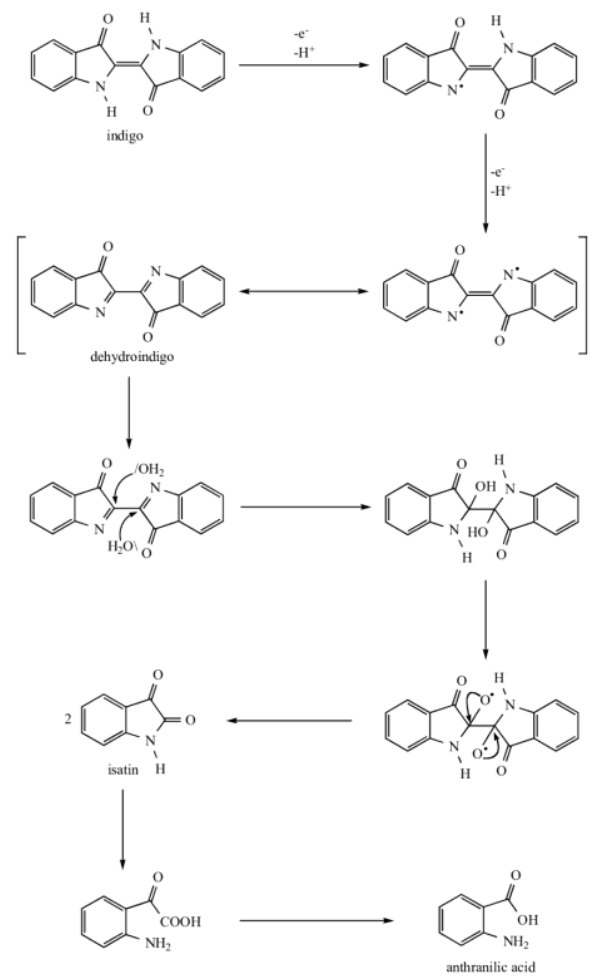

Gambar 5. Mekanisme degradasi pewarna Indigo oleh lakase (Campos et al., 2001)

\section{SIMPULAN}

Tiga Isolat Trametes sp. yang diuji mampu menghasilkan enzim dalam pewarna Indigosol Blue pada konsentrasi glukosa berbeda. Isolat Trametes sp. strain A memiliki aktivitas enzim terbaik dalam pewarna Indigosol Blue dengan konsentrasi glukosa $0,5 \%$.

\section{DAFTAR PUSTAKA}

Abadulla, E., Tzanov, T., Costa, S., Robra, K.H., Cavaco-Paulo, A., Gu“bitz, G. 2000. Decolorization and Detoxification of Textile Dyes with a Laccase from Trametes hirsuta. Applied and Environmental Microbiology, 66(8), pp. 3357-3362.

Ado, B.V., Onilude, A.A., \& Amande, T. 2018. Production and Optimization of Laccase by Trametes sp. Isolate B7 and Its' Dye Decolourization Potential. Journal of Advanced Microbiology, 13(1), pp.1-14.

Campos, R., Kandelbauer, A., Robra, K.H., CavacoPaulo, A., \& Gubitz, G.M. 2001. Indigo Degradation with Purified Laccases from Trametes hirsuta and Sclerotium rolfsii. Journal of Biotechnology, 89, pp.131-139.

Castillo, P.Z. 2012. Purification and Characterization of Laccase from Trametes hirsuta Bm-2 and Its Contribution to Dye and Effluent Decolorization. African Journal of Biotechnology, 11(15), pp. 3603-3611.

Herfiani, Z.H., Rezagama, A., Nur, M. 2017. Pengolahan Limbah Cair Zat Warna Jenis Indigosol Blue (C.I Vat Blue 4) sebagai Hasil Produksi Kain Batik Menggunakan Metode Ozonasi dan Adsorpsi Arang Aktif Batok Kelapa terhadap Parameter COD dan Warna. Jurnal Teknik Lingkungan, 6(3), pp.1-10.

Kapdan, I.K., Kargi, F., McMullan, G., \& Marchant, R. 2000. Effect of Environmental Conditions on Biological Decolorization of Textile Dyestuff by $C$. versicolor. Enzyme and Microbial Technology, 26(5), pp. 381-387.

Kartikasari, T.H., Lestari, S., \& Dewi, R.S. 2012. Adsorpsi Zn dan Dekolorisasi Limbah Batik Menggunakan Limbah Baglog Pleurotus ostreatus dengan Sistem Inkubasi dan Volume Limbah Batik Berbeda. Biosfera, 29(3), pp.168-174.

Kaushik, P., Malik, A. 2009. Fungal Dye Decolourization: Recent Advances and Future Potential. Environment International, 35, pp. 127-141.

Maalej-Kammoun, M., Zouari-Mechichi, H., Belbahri, L., Woodward, S., \& Mechichi, T. 2009. Malachite Green Decolourization and Detoxification by The Laccase from a Newly Isolated Strain of Trametes sp. International Biodeterioration \& Biodegradation, 63(5), pp. 600-606.

Mahfudloh \& Lestari, H. 2017. Strategi Penanganan Limbah Industri Batik di Kota Pekalongan. Skripsi. Semarang: Universitas Diponogoro.

Martina, A., Roza, R.M., \& Sirait, J.R. 2015. Biodegradasi Pewarna Azo Mordant Black 17 Oleh Ganoderma sp. BTA1 Isolat Lokal. 
Prosiding Semirata 2015 bidang MIPA BKSPTN Barat. Universitas Tanjungpura Pontianak.

Mechichi, T., Mhiri, N., \& Sayadi, S. 2006. Remazol Brilliant Blue R Decolourization by The Laccase from Trametes trogii. Chemosphere, 64(6), pp. 998-1005.

Mishra, A., Kumar, S., \& Bhatnagar, A. 2019. Potential of Fungal Laccase in Decolorization of Synthetic Dyes. Microbial Wastewater Treatment, 7, pp. 127-151.

Munir, E., Rahayu V., Priyani, N., \& Yurnaliza. 2018. Decolorization of Batik Naphthol Dye by Local Ligninolytic Fungal Isolates. Journal of Physics: Conference of Science and Technology, 1116, pp.1-7.

Ngieng, N.S., Zulkharnain, A., Roslan, H.A., \& Husaini, A. 2013. Decolourisation of Synthetic Dyes by Endophytic Fungal FloraIsolated from Senduduk Plant (Melastoma malabathricum). ISRN Biotechnology, 2013(7), pp.1-7.

Ottoni, C., Simoes, M.E., Fernandes, S., Santos, C.R., \& Lima, N. 2016. High Laccase Expression by Trametes versicolor in a Simulated Textile Effluent with Different Carbon Sources and PHs. International Journal of Environmental Research and Public Health, 13(8), pp.778-787.

Salleh, M.A.M., Mahmoud, D.K., Karim, W.A., \& Idris, A. 2011. Cationic and Anionic Dye Adsorption by Agricultural Solid Wastes: A Comprehensive Review. Desalination, 280(1), pp.1-13.

Sari, A.A., Tachibana, S., \& Muryanto. 2012. Correlation of Ligninolytic Enzymes from the Newly-Found Species Trametes versicolor U97 with RBBR Decolorization and DDT Degradation. Water Air Soil Pollution, 223, pp.5781-5792.

Sari, A.A. \& Dewi, R.S. 2019. The Study of Basidiomycota and Glomeromycota Biodiversity in Baturraden Botanical Garden, Indonesia. Report Research. Research Grant Programme, NEF.

Senthilkumar, S., Perumalsamy, M., \& Prabhu, H.J. 2014. Decolourization potential of white-rot fungus Phanerochaete chrysosporium on synthetic dye bath effluent containing Amido black 10B. Journal of Saudi Chemical Society, 18, pp. 845-853.
Sulistyaningtyas, A.R. \& Suprihadi, A. 2017. Produksi Miselium Jamur Ling Zhi (Ganoderma lucidum) dalam Medium Air Kelapa Tua dan Tauge Extract Broth dengan Metode Kultur Terendam Teragitasi. Bioma, 19(1), pp. 58-81.

Sumarko, H.G., Lestari, S., \& Dewi, R.S. 2013. Dekolorisasi Limbah Cair Batik Menggunakan Limbah Baglog Pleurotus ostreatus Dengan Kombinasi Volume Dan Waktu Inkubasi Berbeda. Molekul, 8(2), pp. 152-157

Suprihatatin, H. 2014. Kandungan Organik Limbah Cair Industri Batik Jetis Sidoarjo dan Alternatif Pengolahannya. Riau: Pusat Penelitian Lingkungan Hidup Universitas Riau.

Turhan, K., Durukan, I., Ozturkcan, S.A., \& Turgut, Z. 2012. Decolorization of Textile Basic Dye in Aqueous Solution by Ozone. Dyes Pigments, 92(3), pp. 897-901.

Wang, N., Chu, Y., Wu, F., Zhao, Z., \& Xu, X. 2017. Decolorization and Degradation of Congo Red by A Newly IsolatedWhite Rot Fungus, Ceriporia lacerata, from Decayed Mulberry Branches. International Biodeterioration \& Biodegradation, 117(2017), pp. 236-244.

Yesilada, O., Birhanli, E., \& Geckil, H. 2018. Bioremediation and Decolorization of Textile Dyes by White Rot Fungi and Laccase Enzymes. In: Prasad R. (eds) Mycoremediation and Environmental Sustainability. India: Springer International Publishing.

Zahra. 2017. Studi Dekolorisasi Lindi Hitam dengan Teknik Ramah Lingkungan Menggunakan Jamur Trametes versicolor F200 dan Isolat Enzimnya yang Diimobilisasikan pada Natrium Alginat. Thesis. Depok: Universitas Indonesia.

Zapata-Castillo, P., Villalonga-Santana, L., IslasFlores, I., Rivera-Mu noz, G., AnconaEscalante, W., \& Solis-Pereira, S. 2015. Synergistic Action of Laccases from Trametes hirsuta $\mathrm{Bm} 2$ Improves Decolourization of Indigo Carmine. Applied Microbiology, 61, pp. 252-258.

Zavarzina, A.G., \& Zavarzin, A.A. 2006. Laccase and Tyrosinase Activities in Lichens. Microbiology, 75(5), pp. 546-556. 